\title{
Study on the Status Quo of College Students' Scientific Quality in Private-owned Universities
}

\author{
Qiuju Zeng \\ Huanghe Science \& Technology University \\ Zhengzhou, China, 45006
}

\begin{abstract}
This article is making a sample survey of college students' scientific literacy in private-owned unversities. The statistic report shows that college students' scientific literacy in private-owned universities has not accorded with the time requirement made by the country, and there has been a distance from the quality goal that is being aimed towards college students. In terms of these issues, this paper proposes some methods to strengthen and improve the college students' scientific literacy in private-owned universities.
\end{abstract}

Keywords-Private-owned universities; college students; scientific literacy

\section{INTRODUCTION}

The scientific quality education of citizens is very important to the capability of a state sustainable development. The scientific quality is an important part of the individual quality, and it is the inner quality and the potential ability of an individual who does some research activities. If we want to cultivate students' creative and pracitical ability, it is quite necessary to have a knowledge of the status quo of college students' scientific quality. To have more knowledge of the college students' scientific quality in private-owned universities, to provide more evidence for cultivating and estimating college students' scientific quality, to extensively carry forward the task of college students' quality education, and to increase the efficiency of cultivating college students, part of college students are the subjects of private-owned universities in Henan province in this reasearch, and questionnaire is given to them in this study.

\section{THE ANALYSIS OF THE SURVEY DATA}

\section{A. The cognitive situation of college students towards scientific quality in private-owned universities}

Through the research result in questionnaire, college students in private-owned universities have some knowledge of scientific quality, and they know what they lack, but most of them just know what is the problem, and they do not take any action. They should have spent time in scientific pograms, scientific development and technology programs if they have tme, however, they seldom do these things. 50\% of them are sometimes concerned with such topics, while $20 \%$ of them have never taken any activities in college.

\section{B. Students'scientific knowledge in private-owned universities}

Through the statistic results, many college students have some knowledge of science, but there are some who are not so clear about the scientific knowledge. And some are not clear about the understanding of some scientific terms. In the research of students'science, we cannot get $80 \%$ right answers. About some basic scientific knowledge, the right rate is all right. Most of them are just concerned with what the are interested in, so they spent little time in the advanced and new technological field.

Through newspapers, radio and television publicity, students know more about such knowledge as cloning, radiation, and windows operating systems, but sucn knowledge as "quantum computer", they know little, and as shown in Table one, $46.04 \%$ of students say they are not clear. From the table, for most scientific terms, whether common or frontier, the degree of understanding of most students is limited to "some understanding". There are few who are very clear about this part of knowledge. This shows the breadth and depth of scientific knowledge is not enough for college students.

\section{Scientific spirit of students in private-owned universities}

Scientific spirit refers to the common belief, value and behavior standards that people have formed in long-time scientific practice. The spirit of science, which is determined by science nature, refers to the basic mental state and thinking mode in the scientific activities. And it is reflected in the ideas or concepts of the scientific knowledge. In the evaluation of the behavior of Bruno, 72.66\% students choose the "admiration not imitation", 9.45\% choose "admiration and imitation," which shows that students have some basic understanding of the scientific spirit, but they're lack of inner experience of scientific meanings and inner will and devotion to scientific behavior, are more lack of the spirit of defending the truth. There's even $17.89 \%$ students who do not appreciate Bruno's behavior. All of this shows that students in private universities lack the deep understanding of scientific spirit.

\section{Scientific awareness of students in private-owned universities}

Scientific awareness refers to a profound understanding of social attitudes in essence, function, development law and mechanisms formed on the basis of science, which can promote people to join the cause of science, or make a positive response to scientific activities and participation in scientific 
activities. As well, it can provide reasonable values guidance for scientific activities. With the social development and advancement of technology, students' scientific awareness has significantly been increasing. The survey data show that $50 \%$ students seldom choose "divination fortune, Duke Dream" or "computer-telling, horoscopes" settlement when they are encountered with difficulties. $80 \%$ students will choose to find "friends communication". $60 \%$ students choose to find teacher-student communication. However, there are $20 \%$ who often select "lottery fortune, Duke Dream" or "computer-telling, horoscopes" and other means when they have some problems. This shows that the traditional feudal superstition is still influencing some citizens in a short time, and this shows that some college students' ability to distinguish pseudo-science needs to be further improved.

Survey shows that most students can objectively recognize the positive and negative impacts of science and technology on our society. More than $60 \%$ of the students are fully affirmed the role of science and technology, which determines the standard of living, national prosperity, moral standards, public health, and equality in the world and which plays a positive role.

\section{III.MEASURES OF CULTIVATING STUDENTS' SCIENTIFIC LITERACY IN PRIVATE-OWNED UNIVERSITIES}

Seen from the statistics, the majority of private college students have mastered a certain amount of scientific knowledge, but their whole science consciousness is generally not high and the scientific spirit is not strong. Scientific quality of college students does not accord with requirements on innovative talents of the times, there is a certain distance from our quality education objectives and requirements. Therefore, for the current state of scientific, colleges should take effective measures to improve the scientific quality of students.

\section{A. To foster the scientific spirit, respect for science, the pursuit of truth}

Stable outlook and philosophy of life is that people 's attitude towards the value of life , the purpose of life issues such as standards. Once it is formed, it will become a guide to determine the direction and the way of a person's life. Scientific outlook on life will derive many excellent quality, firm and enthusiastic spirit, noble ideological level. College students are in their mid- youth ( 18 to 20 years old ). This stage is in severe psychological turning point, which is rapidly becoming a mature physical development, psychological maturity not yet reached in reality. They will encounter a lot of " growing pains ." Their needs and values of this period is characterized by the performance of its practical side, as well as, the idealistic side. Facts have proved that, if a person has a correct outlook on life, the life sciences, which will derive a lot of excellent quality, firm and enthusiastic spirit, noble ideological level, as well as the face of frustration tolerance. So, they will do better than other people on many aspects if they have these qualities.

\section{B. To establish a cultural atmosphere of scientific spirit}

People are not born with the spirit of science, and this spirit should be fostered by creating a science atmosphere. Scientific spirit on campus generally refers to the organic integration of the campus spiritual culture and material culture, specificly, the impact on the education of students taught on campus. Integration and development of the campus, including historical and cultural heritage and emerging cultural synthesis of many common characteristics and development direction education schools, it has both material and cultural content, but also the spiritual and cultural content, as well as thinking, behavior, consciousness, institutional, cultivation methods and other aspects of content. Thus, the construction of cultural spirit on campus will have a great impact on the development of colleges, ad well as the forming of sutdents' world value.

Based on the requirements of teachers and academic development for teachers and students, universities should create a strong spiritual atmosphere, invite internal and external academic experts, professors to hold a series of academic lectures. Teachers should also make contributions to create a healthy campus culture which plays an important role in the construction of science spirit on campus. In addition, there should be some rules and regulations to regulate students' behavior. In today's social climate, it is quite necessary to set severe rules and regulations for young students.

\section{To promote the teaching reform, focus on training scientific methods}

Institutions of higher education in particular is to develop the scientific spirit of private colleges and universities should take the initiative to adapt to the needs of building an innovative country, changing concepts, deepening reform.

\section{To do well in the development of teaching content}

These courses should be added into the original curriculum system. They are those that aim at fostering college students' scientific spirit and ideas, and they should be given some credit. Meanwhile, to set up an interdisciplinary curriculum is an effective way to develop the scientific quality of college students. The goal of enhancing college students' overall quality can be achieved only if their scientific quality, arts quality and social cultural quality are developed together.

\section{E. To update the curriculum design}

The survey shows that there are too many courses for students in private universities, and their burden is too heavy. Therefore, it is necessary to reduce their task and duplication of courses. And the teaching content should be updated with the times. And teachers should prepare their lectures that can reflect the frontier of thier field. At the same time, those courses which can foster students' scientific spirit should be designed. Students' cooperative awareness and creativity should be cultivated in the teaching process.

\section{F. To reform the traditional teaching methods}

When we cultivate the spirit of science, work of changing the traditional education mode should be done. Students' subjective dynamic role should be emphasized. In traditional classes, sutdents are just listening to their teachers, but in the new teaching mode, students should take active role. They learn, create and experience. In this process, they can learn 
more, and their creative ability, their scientific quality can be enhanced.

G. To enrich campus technological innovation activities and to enhance college students' scientific and technological innovation capability

The training of the scientific quality is to build the main structure of the corresponding mental process, it can be formed and developed through learning, behavior and practice, and can be gradually grown in the body in the form of a relatively stable way of thinking and behavior. Scientific practice is an important way to enhance college students' scientific literacy, creative ability and learning science. So, colleges should recognize some various high-level activities concerning science and technology, such as technological reading, reports given by famous experts and some competitive invention activities. In addition, to increase the strength of college holidays technology services, to establish science and technology practice activities, to organize and guide students to actively participate in science and technology to the countryside services, science promotion activities, all of this play the main role in promoting students to love science, use science to promote scientific behavior. This helps students to form a sense of responsibility to contribute to society and enhance the technological innovation capability college. In the course of the activity, the goal of self-education and self-improvement can be achieved, and students can form a good scientific way of life.

\section{REFERENCES}

[1] Meng Zi, Wang.Scientific Quality Education on College Students and Countermeasures [D], Wuhan: Wuhan University of Technology, 2010.

[2] American Association for the Advancement of Science. China Science and Technology Association translation science education reform blueprint [M]. Popular Science Press, 2001.

[3] WeiZe. Investigation and analysis of the scientific quality of the Students in China [J]. Guangzhou Radio and Television University, $2010(5): 44-47$ 